\title{
SHORT-TERM REPEATABILITY OF CONTRALATERAL SUPPRESSION OF TRANSIENTLY EVOKED OTOACOUSTIC EMISSIONS: PRELIMINARY RESULTS
}

\author{
W. Wiktor Jedrzejczak ${ }^{1,2}$, Edyta Pilka ${ }^{1,2}$, Lukasz Olszewski ${ }^{1,2}$, Henryk Skarzynski ${ }^{1,2}$ \\ ${ }^{1}$ Institute of Physiology and Pathology of Hearing, Warsaw, Poland \\ ${ }^{2}$ World Hearing Center, Nadarzyn, Kajetany, Poland
}

Corresponding author: W. Wiktor Jedrzejczak, World Hearing Center, Institute of Physiology and Pathology of Hearing, Mochnackiego 10 Str., 02-042 Warsaw, Poland, e-mail: w.jedrzejczak@ifps.org.pl

\begin{abstract}
Background: The effect of suppression of otoacoustic emissions (OAEs) by contralateral acoustic stimulation (CAS) is very small, on the level of 1-2 dB. At the same time, OAEs are known to have quite high variability across subjects and some fluctuation of the signal between measurements is also present. The purpose of the present study was to investigate short-term repeatability of contralateral suppression of transiently evoked OAEs (TEOAEs).
\end{abstract}

\begin{abstract}
Material and methods: OAEs were recorded in a group of 10 adults with normal hearing. TEOAEs were recorded using the linear protocol (all stimuli at the same level and polarity); stimulus levels were kept at $65 \mathrm{~dB}$ peSPL; and a $60 \mathrm{~dB}$ SPL broadband noise was delivered to the contralateral ear as suppressor. Each recording session consisted of three measurements: the first two were made consecutively without taking out the probe ('single fit' mode); the third measurement was made after taking out and refitting the probe ('multiple fit' mode). Global and half-octave values of TEOAE response levels and suppression were investigated. Additionally, as a measure of reliability, standard errors of measurement (SEMs) were analyzed.
\end{abstract}

Results: Broadband suppression was on average around $0.9 \mathrm{~dB}$, while in the three half-octave frequency bands between 1 and $2 \mathrm{kHz}$ it was $1.2-0.9 \mathrm{~dB}, 0.6 \mathrm{~dB}$ for the $2.8 \mathrm{kHz}$ band, and $0.4 \mathrm{~dB}$ for the $4 \mathrm{kHz}$ band. The SEM of suppression for single fit mode was about $0.15 \mathrm{~dB}$ for broadband analysis and $0.3 \mathrm{~dB}$ for $1 \mathrm{kHz}, 0.2 \mathrm{~dB}$ for $1.4-2 \mathrm{kHz}, 0.3 \mathrm{~dB}$ for $2.8 \mathrm{kHz}$, and $0.4 \mathrm{~dB}$ for $4 \mathrm{kHz}$. For multiple fits, there were only minor differences in SEM between broadband and 1-2.8 kHz, while for $4 \mathrm{kHz}$ the SEM was greater, reaching $0.5 \mathrm{~dB}$.

Conclusions: For a given paradigm, the reliability of suppression of TEOAEs is quite satisfactory for global values and for the 1-2 kHz bands. In this range, the SEM is smaller than the suppression effect. On the other hand, for higher frequencies, the variability is higher, about the same as the measured suppression.

Keywords: transiently evoked otoacoustic emissions $\bullet$ TEOAE $\bullet$ contralateral suppression • reliability • repeatability

\section{LA REPETIBILIDAD A CORTO PLAZO DE LA SUPRESIÓN CONTRALATERAL DE} LAS OTOEMISIONES ACÚSTICAS TRANSITORIAS: RESULTADOS PRELIMINARES

\section{Resumen}

Introducción: La supresión de otoemisiones acústicas (OAE) durante la estimulación acústica contralateral (CAS) es muy débil, a un nivel de 1-2 dB. Al mismo tiempo, se sabe que OAE tienen diferencias muy grandes entre las personas. También existen las fluctuaciones del señal entre las mediciones. El objetivo del presente trabajo fue examinar la repetibilidad a corto plazo de la supresión contralateral de las otoemisiones acústicas transitorias (TEOAE).

Material y métodos: Las OAE fueron medidas en el grupo de 10 adultos con la audición normal. Las TEOAE fueron registradas con el uso del protocolo lineal (todos los estímulos al mismo nivel y de la misma polaridad); los niveles de los estímulos ascendieron a $65 \mathrm{~dB}$ peSPL; el ruido de banda ancha fue suministrado a la oreja opuesta como el supresor. Cada sesión de medición consistió en tres mediciones: las primeras dos fueron hechas sucesivamente sin retirar la sonda (modo de ajuste solo); la tercera fue hecha después de retirar y reinsertar la sonda (modo de ajuste múltiple). Se examinó los valores globales y de media octava de los niveles de respuestas y supresiones. Además, se analizó los errores estándares de medida (SEM).

Resultados: La supresión de banda ancha fue alrededor de $0,9 \mathrm{~dB}$, por término medio, mientras que en 3 bandas de frecuencia de media octava de 1 a $2 \mathrm{kHz}$ fue $1,2-0,9 \mathrm{~dB}, 0,6 \mathrm{~dB}$ para la banda de $2,8 \mathrm{kHz}$ y $0,4 \mathrm{~dB}$ para la banda de $4 \mathrm{kHz}$. SEM de la supresión para el modo de ajuste solo fue alrededor de $0,15 \mathrm{~dB}$ para el análisis de banda ancha y $0,3 \mathrm{~dB}$ para $1 \mathrm{kHz}, 0,2 \mathrm{para}$ 
1.4-2 kHz, 0,3 dB para $2,8 \mathrm{kHz}$ y 0,4 dB para $4 \mathrm{kHz}$. Para el modo de ajuste múltiple solo habían pequeñas diferencias en SEM para los valores de banda ancha y $1-2.8 \mathrm{kHz}$, y para $4 \mathrm{kHz}$ SEM fue mayor, llegando a $0,5 \mathrm{~dB}$.

Conclusiones: Para el protocolo de medición utilizado, la repetibilidad de la supresión TEOAE es satisfactoria para el análisis de banda ancha y para bandas de frecuencia 1-2 kHz. En este rango SEM es menor que la supresión. Por otra parte, para las frecuencias mayores, la variabilidad es mayor, más o menos al mismo nivel que la supresión.

Palabras clave: otoemisiones acústicas transitorias • TEOAE • supresión contralateral • credibilidad • repetibilidad

\section{КРАТКОСРОЧНАЯ ПОВТОРЯЕМОСТЬ КОНТРАЛАТЕРАЛЬНОЙ СУПРЕССИИ ОТОАКУСТИЧЕСКИХ ЭМИССИЙ, ВЫЗВАННЫХ ТРЕСКОМ: ПРЕДВАРИТЕЛЬНЫЕ РЕЗУЛЬТАТЫ}

\section{Изложение}

Введение: При контралатеральной акустической стимуляции (CAS) супрессия отоакустических эмиссий (OAE) очень слаба, на уровне 12-дБ. Одновременно известно, что в случае ОАЕ между пациентами существует очень большая вариабельность. Появляются также колебания сигнала между измерениями. Цель настоящей работы заключалась в исследовании краткосрочной повторяемости контралатеральной супрессии отоакустических эмиссий, вызванных треском (TEOAЕ).

Материалы и методы: Измерения ОАЕ проводиись в группе 10 взрослых людей обладающих нормальным слухом. ТЕОАЕ регистрировалась с помощью горизонтального протокола (все стимулы на одинаковом уровне и с одинаковой поляризацией); уровни стимулов: 65 дБ peSPL; в качестве супрессора в противоположное ухо попадал широкополосный шум. Каждая сессия измерений состояла из трех измерений: первые два выполнялись последовательно, зонд не извлекался (режим «единичного приспособления»); третье измерение проводилось после извлечения и повторного размещения зонда (режим «многократного приспособления»). Исследовались глобальные и полуоктавные значения уровней ответов и супрессий. Дополнительно анализировались стандартные погрешности измерений (SEM).

Результаты: Широкополосная супрессия составляла в среднем около 0,9 дБ, в то время как в случае 3 полуоктавных полос частотой 12-кГц составлял 1,20-0,9 дБ, 0,6 дБ в случае полосы 2,8 кГц и 0,4 дБ в случае полосы 4 кГц. SEM супресси в случае режима единичного приспособления составила около 0,15 дБ для широкополосного анализа и 0,3 дБ для 1 кГц, 0,2 для 1.42-кГц, 0,3 дБ для 2,8 кГц и 0,4 дБ для 4 кГц. В случае режима многократного приспособления появились только незначительные различия SEM для широкополосных значений и 1-2.8 кГц, а для 4 кГц SEM была выше, достигая уровня 0,5 дБ.

Выводы: В случае использованного протокола измерений повторяемость супрессии ТЕОАЕ является удовлетворительной для широкополосного анализа и полос частотой 12-кГц. В этом диапазоне уровень SEM ниже чем уровень супрессии. С другой стороны в случае более высоких частот переменчивость выше, более-менее на таком же уровне, как супрессия.

Ключевые слова: отоакустические эмиссий, вызванные треском • ТЕОАЕ • контралатеральная супрессия • достоверность • повторяемость

\section{KRÓTKOTERMINOWA POWTARZALNOŚĆ SUPRESJI KONTRALATERALNEJ EMISJI OTOAKUSTYCZNYCH WYWOŁANYCH TRZASKIEM: WYNIKI WSTĘPNE}

\section{Streszczenie}

Wprowadzenie: Supresja emisji otoakustycznych (OAE) przy kotralateralnej stymulacji akustycznej (CAS) jest bardzo słaba, na poziomie 1-2 dB. Jednocześnie wiadomo, że OAE mają bardzo duże różnice międzyosobnicze. Występują także fluktuacje sygnału pomiędzy pomiarami. Celem niniejszej pracy było zbadanie krótkoterminowej powtarzalności supresji kontralateralnej emisji otoakustycznych wywołanych trzaskiem (TEOAE).

Materiał i metody: OAE zmierzono w grupie 10 osób dorosłych z normalnym słuchem. TEOAE rejestrowano stosując protokół liniowy (wszystkie bodźce na tym samym poziomie i o tej samej polaryzacji); poziomy bodźców wynosiły $65 \mathrm{~dB}$ peSPL; jako supresor do ucha przeciwnego był dostarczany szerokopasmowy szum. Każda sesja pomiarowa składała się z trzech pomiarów: pierwsze dwa wykonywano kolejno bez wyjmowania sondy (tryb „pojedynczego dopasowania”); trzeci pomiar wykonywano 
po wyjęciu i ponownym umieszczeniu sondy (tryb „wielokrotnego dopasowania”). Badano wartości globalne i półoktawowe poziomów odpowiedzi i supresji. Dodatkowo, analizowano standardowe błędy pomiaru (SEM).

Wyniki: Szerokopasmowa supresja wynosiła średnio około $0,9 \mathrm{~dB}$, podczas gdy w 3 pasmach półoktawowych częstotliwości od 1 do $2 \mathrm{kHz}$ wynosił 1,2-0,9 dB, 0,6 dB dla pasma $2,8 \mathrm{kHz}$ i $0,4 \mathrm{~dB}$ dla pasma $4 \mathrm{kHz}$. SEM supresji dla trybu pojedynczego dopasowania wynosił około $0,15 \mathrm{~dB}$ do analizy szerokopasmowej i $0,3 \mathrm{~dB}$ dla $1 \mathrm{kHz}, 0,2 \mathrm{dla} 1,4-2 \mathrm{kHz}, 0,3 \mathrm{~dB} \mathrm{dla} 2,8 \mathrm{kHz}$ i $0,4 \mathrm{~dB}$ dla $4 \mathrm{kHz}$. Dla trybu wielokrotnego dopasowania były tylko drobne różnice w SEM dla wartości szerokopasmowych i $1-2.8 \mathrm{kHz}$, a dla $4 \mathrm{kHz}$ SEM był większy, osiągając $0,5 \mathrm{~dB}$.

Wnioski: Dla użytego protokołu pomiarowego, powtarzalność supresji TEOAE jest zadowalająca dla analizy szerokopasmowej oraz dla pasm częstotliwości 1-2 kHz. W tym zakresie SEM jest niższy niż supresja. Z drugiej strony, dla wyższych częstotliwości, zmienność jest większa, mniej więcej na takim samym poziomie, jak supresja.

Słowa kluczowe: emisje otoakustyczne wywołane trzaskiem • TEOAE • supresja kontralateralna • wiarygodność • powtarzalność

\section{Introduction}

Otoacoustic emissions (OAEs) are now well established objective tests of cochlear function [1]. Recently, substantial research effort has focused on evaluating the influence of the olivocochlear efferent system on OAEs. The medial olivocochlear (MOC) part of this system runs from brainstem to outer hair cells in the cochlea. The role of MOC is not fully understood, but it has been attributed to protection against acoustic trauma [2], improving hearing in noisy environments [3], and also a relationship to attention [4]. In the presence of additional stimuli - ipsilateral, contralateral, or bilateral - the efferent system suppresses OAEs $[5,6]$. Of most interest is contralateral stimulation by broadband noise [6], as this is the easiest way to measure the effect. For transiently evoked OAEs (TEOAEs), the effect is quite small, only $1-1.5 \mathrm{~dB}[7,8]$.

To date, contralateral suppression of OAEs has been studied in several clinical populations. In comparison to normal subjects, the effect differs depending on the group studied: diabetic children $[9,10]$, children with Asperger syndrome [11], and workers at risk of occupational hearing loss [12]. There are also some contradictory results regarding subjects with tinnitus, with some papers finding a difference in comparison to normal subjects [13] while others do not [14].

There are few studies on the variability and repeatability of the MOC effect. Results indicate that, averaged across subjects, variability is up to $0.1 \mathrm{~dB}[8,15,16]$. Many studies of the MOC effect on OAEs have used either custombuilt systems (e.g. [15,17]) or a combination of commercial OAE system plus additional noise source (e.g. $[8,18])$. For some time now, measurement of contralateral suppression has been available in the commercial ILO system by Otodynamics (Hatfield, U.K.). It is therefore of interest to clinicians to know how such a system performs and its measurement reliability (its repeatability). As far as the authors know, there is only one study of ILO reliability using its standard suppression protocol [16] (although the study did involve some minor changes to the protocol: a click stimulus of $60 \mathrm{~dB}$ peSPL and contralateral broadband noise of $65 \mathrm{~dB}$ SPL, whereas the default uses $65 \mathrm{~dB}$ and $60 \mathrm{~dB}$ respectively). Details of the procedure used here are described in the 'Material and Methods' section. Moreover, there has been no study that has investigated the repeatability of contralateral suppression of TEOAEs in half-octave bands using the standard clinical protocol. Generally, most studies use only global values of TEOAEs.

The repeatability of TEOAEs themselves has also not been studied much. For example, in one paper [19], it was found that fluctuations in TEOAE levels were typically around 1-2 $\mathrm{dB}$, but in some ears they reached as much as $5 \mathrm{~dB}$. This is well above the usual MOC effect. It therefore seems that variability in TEOAE levels could be important for evaluating MOC function.

Given that measurement of MOC effects using TEOAEs provides the opportunity to study a number of interesting features (even though the effect is small), the purpose of this study was to evaluate the short-term repeatability (single session reliability) of MOC suppression of TEOAEs using the commercially available ILO system.

\section{Material and methods}

Measurements were performed on 10 normally hearing adults ( 5 males and 5 females, age $28-43$ years). Each ear was tested, so in total results from 20 ears were used for all analyses. Between-ear effects were not studied and ears were treated as if they were independent. This is obviously a simplification, but it is based on the observation that the OAEs from both ears of the same person are usually quite different [20].

All subjects underwent visual inspection of the ear canal and tympanic membrane of both ears, followed by tympanometry, middle ear reflexes, pure tone audiometry, and OAE measurement. All had pure tone thresholds better than $25 \mathrm{~dB} \mathrm{HL}$ at $0.5-8 \mathrm{kHz}$, type A tympanograms (with middle ear compliance between 0.25 and $1.5 \mathrm{~mL}$, and middle ear pressure between -100 and $50 \mathrm{daPa}$ ), and no known history of otologic disease. In all subjects, middle ear acoustic reflex thresholds for broadband noise were above $65 \mathrm{~dB}$ SPL. The subjects gave written informed consent prior to participation. Research procedures were approved by the Ethics Committee of the Institute of Physiology and Pathology of Hearing, Poland.

OAEs were measured in a sound booth using an ILO 292 system (Otodynamics Ltd.). The standard protocol, with default settings, for measurement of contralateral suppression was used. In the protocol, $65 \mathrm{~dB}$ peSPL click 
stimuli are delivered to one ear and $60 \mathrm{~dB}$ peSPL broadband (white) noise to the contralateral ear. Masker on/off time is $2 \mathrm{~s}$, and a total of 260 OAE sweeps are used. Global and half-octave band values of OAE response levels and signal-to-noise ratios (SNRs) were used for analysis. All recordings had an SNR of at least $6 \mathrm{~dB}$ for global values and $3 \mathrm{~dB}$ in half-octave bands frequencies from 1 to $4 \mathrm{kHz}$.

Each recording session consisted of three measurements. The first two were made consecutively without taking out the probe - single-fit mode. The third measurement was made after taking out and refitting the probe - multiplefit mode. Each measurement took 2-3 minutes, and the whole set of measurements for one ear took up to $10 \mathrm{~min}$ utes. Measurement sessions were between 6 am and $4 \mathrm{pm}$.

For all parameters, the statistical significance of the mean difference between the three measurements was evaluated using two-factor (frequency and measurement) repeated measures ANOVA. As a criterion of significance, a 95\% confidence level $(p<0.05)$ was chosen.
Some studies recommend use of the standard error of measurement (SEM) as a measure of reliability [21]. It is based on the formula:

$$
\mathrm{SEM}=\mathrm{STD} \sqrt{1-r}
$$

where STD is the combined standard deviation of the OAE test and its retest and $r$ is the Pearson correlation coefficient. In all calculations the SEM was calculated for absolute values.

\section{Results}

\section{TEOAE repeatability}

As a first step, TEOAE response levels and TEOAE reliability were investigated. For this purpose, the signals recorded with a $65 \mathrm{~dB}$ SPL click stimulus but without contralateral stimulation were analyzed. TEOAE1 and TEOAE2 were made without refitting the probe, and TEOAE3 was made after refitting it. Average broadband response levels were around $12 \mathrm{~dB}$ (Figure 1A), SNRs were around $18 \mathrm{~dB}$ (Figure 1B), and results for consecutive sessions were very similar. When frequency bands were tested, the levels were

A

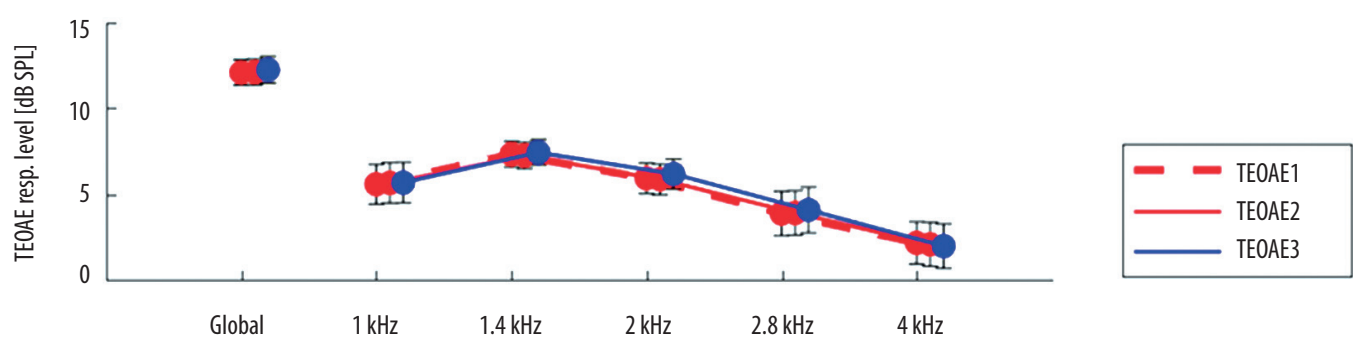

B

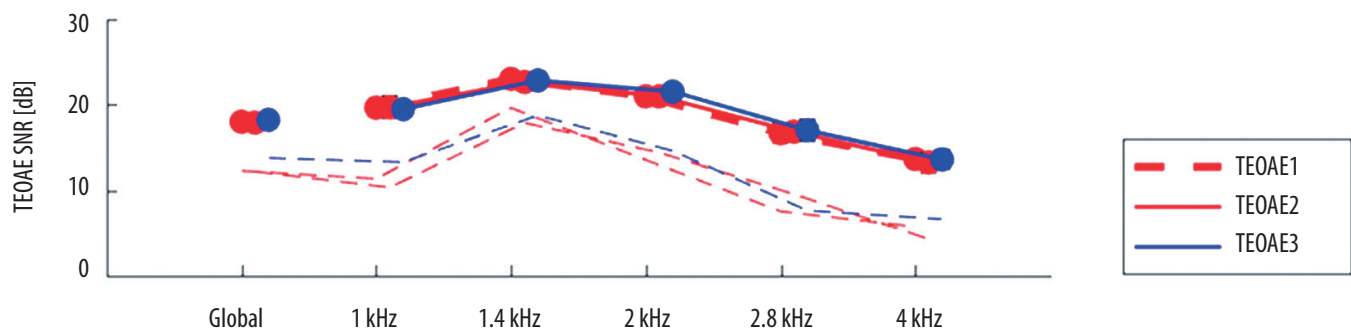

C

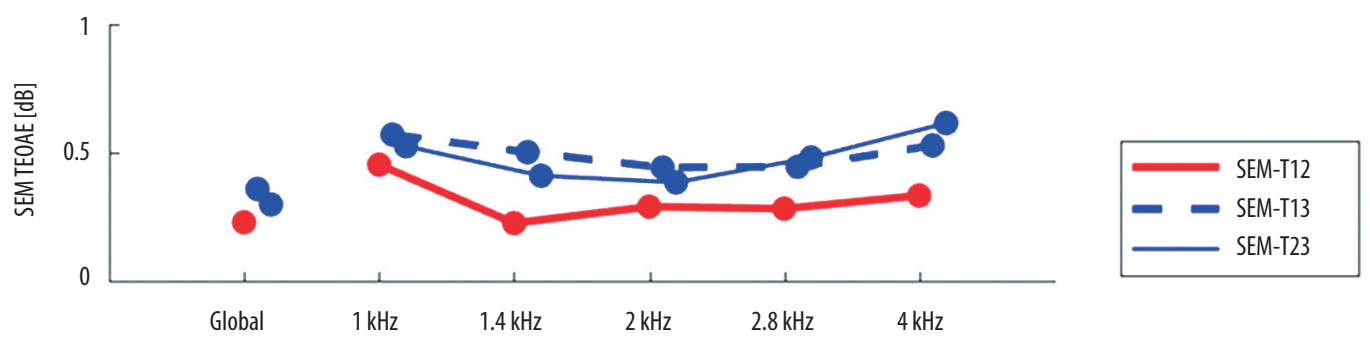

Figure 1. Results from three consecutive measurement sessions of TEOAEs. (A) Average global and half-octave band response levels. Whiskers indicate standard errors. (B) Average global and half-octave band signal to noise ratios (SNRs) (dashed lines show minimum SNRs for studied data). (C) Global and half-octave band standard errors of measurement (SEMs) for TEOAE levels. Differences between sessions 1 and 2 (T12), 1 and 3 (T13), and 2 and 3 (T23) are shown. Data points are slightly offset for clarity 
A A
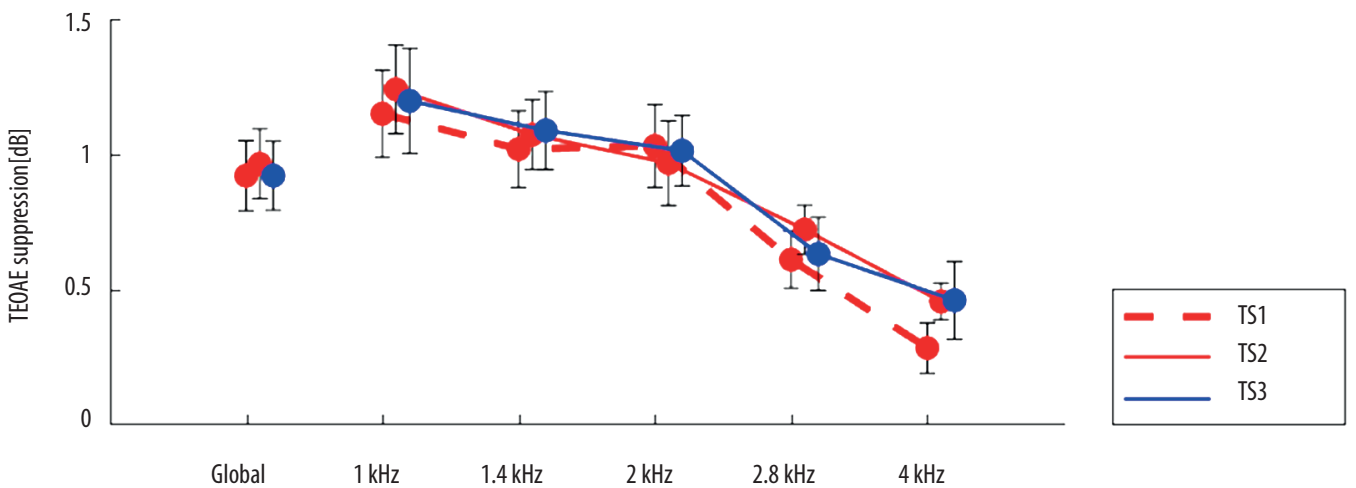

B

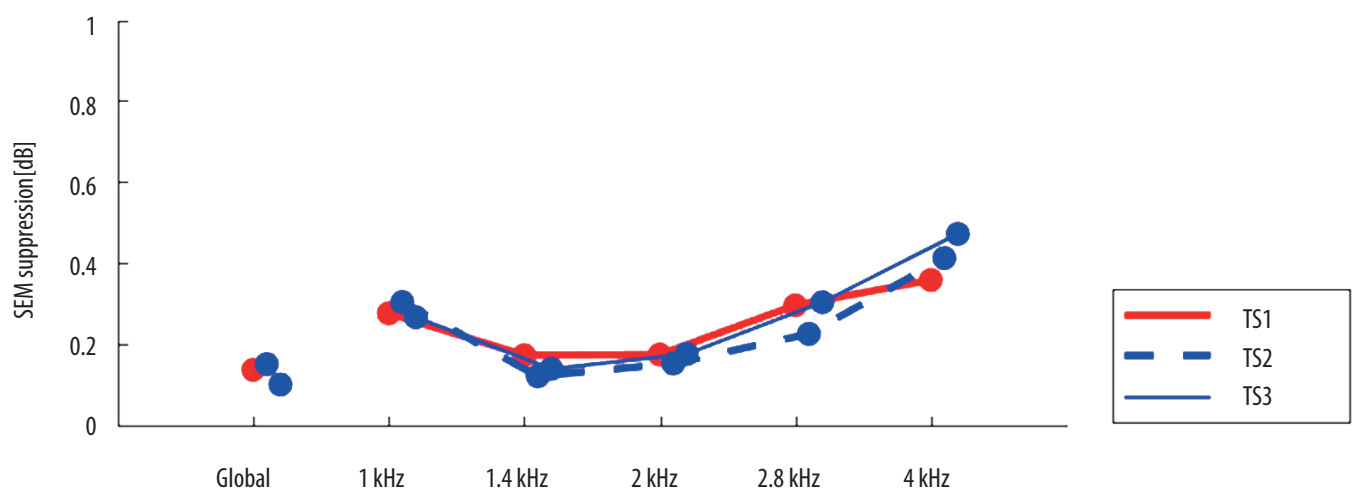

Figure 2. (A) Average global and half-octave band levels of suppression for TEOAEs across three consecutive measurement sessions (TS1, TS2, and TS3). Whiskers indicate standard errors. (B) Global and half-octave band SEMs for differences in suppression between measuring sessions (key as per Figure 1). For clarity, data points are slightly offset

around $5.6 \mathrm{~dB}$ for $1 \mathrm{kHz}, 7.3 \mathrm{~dB}$ for $1.4 \mathrm{kHz}, 5.9 \mathrm{~dB}$ for $2 \mathrm{kHz}, 3.8 \mathrm{~dB}$ for $2.8 \mathrm{kHz}$, and $2.1 \mathrm{~dB}$ for $4 \mathrm{kHz}$. A twofactor repeated measures ANOVA did not show statistically significant differences between TEOAE1, TEOAE2, and TEOAE3, for frequency or for measurement $(p>0.05)$. There were no significant differences for global values either $(p>0.05)$.

SEM was used as a measure of reliability of TEOAEs (Figure 1C). The SEM calculated for sessions 1 and 2 (without refitting the probe) is marked as SEM-T12, and for consecutive sessions SEM-T13 and SEM-T23 (after refitting the probe). The global value of SEM-T12 was $0.22 \mathrm{~dB}$, while the value for SEM-T13 was $0.36 \mathrm{~dB}$ and for SEM-T23 it was $0.3 \mathrm{~dB}$. SEM was lowest for the middle frequency bands of $1.4-2.8 \mathrm{kHz}$ and highest for the 1 and $4 \mathrm{kHz}$ bands.

\section{TEOAE contralateral suppression repeatability}

Figure 2 shows the results of contralateral suppression of TEOAEs for three consecutive measurements. The amount of suppression was calculated by subtracting the response with contralateral noise from the response without noise (TEOAE1, TEOAE2, and TEOAE3, shown in Figure 1). TS1 and TS2 were made without refitting the probe, and TS3 was made after refitting it.

Broadband suppression was on average around $0.9 \mathrm{~dB}$, while in half-octave frequency bands it was $1.2-0.9 \mathrm{~dB}$ in the three frequency bands between 1 and $2 \mathrm{kHz}, 0.6 \mathrm{~dB}$ for the $2.8 \mathrm{kHz}$ band, and $0.4 \mathrm{~dB}$ for the $4 \mathrm{kHz}$ band (Figure $2 \mathrm{~A}$ ). Generally, the amount of suppression was similar across sessions. A two-factor (frequency and measurement) repeated measures ANOVA showed no statistically significant differences between any of the frequencies or any of the series, including the session where the probe was refitted.

The SEM of suppression for the single fit mode (SEM-S12) was around $0.15 \mathrm{~dB}$ for broadband analysis and $0.3 \mathrm{~dB}$ for $1 \mathrm{kHz}, 0.2 \mathrm{~dB}$ for $1.4-2 \mathrm{kHz}, 0.3 \mathrm{~dB}$ for $2.8 \mathrm{kHz}$, and 0.4 $\mathrm{dB}$ for $4 \mathrm{kHz}$ (Figure $2 \mathrm{~B}$ ). There were only minor differences in SEM for multiple fits (SEM-S13 and SEM-S23) for broadband and for the $1-2.8 \mathrm{kHz}$ bands, while the SEM for $4 \mathrm{kHz}$ was greater, reaching $0.5 \mathrm{~dB}$.

\section{Discussion}

In the present work measurements have been made of the short-term reliability of the response level of TEOAEs and the amount of suppression caused by contralateral broadband noise. It should be noted that TEOAEs were here measured at $65 \mathrm{~dB}$ in the linear averaging mode, although usually TEOAEs are measured using a level of $80 \mathrm{~dB}$ in the nonlinear averaging mode [22]. Note also that in most studies involving OAE suppression measurements, other protocols are used than the one employed here. 
Using the present paradigm, the average suppression level was around $1 \mathrm{~dB}$ for the broadband signal. This is in agreement with some other studies [16]. In half-octave frequency bands it was also around $1 \mathrm{~dB}$ for $1-2 \mathrm{kHz}$ and lower values, around $0.5 \mathrm{~dB}$, were recorded for $2.8-4$ $\mathrm{kHz}$. This distribution of the MOC effect across frequencies is similar to [23]; however in that work higher effect levels were found.

As for the reliability of the effect, it was better than $0.2 \mathrm{~dB}$ for broadband values and better than $0.3 \mathrm{~dB}$ for the $1-2.8 \mathrm{kHz}$ bands, but close to $0.5 \mathrm{~dB}$ for the $4 \mathrm{kHz}$ band. In $[8,16]$, even lower average test differences were found for broadband values: around $0.01-0.05 \mathrm{~dB}$ in the first study and $0.11 \mathrm{~dB}$ in the second. However, the data spread was quite high. On the other hand, in [17] it was concluded that variability of the MOC effect is quite high and even 1.5-2 $\mathrm{dB}$ of suppression is required for the change to be considered significant. The reliability of the MOC effect in particular frequency bands has so far been studied only by [18]. The results were comparable to the present study in that it was concluded that the $0.5-2.5 \mathrm{kHz}$ band gave the best results. The high variability of the MOC effect at $4 \mathrm{kHz}$ in the present study can be attributed to a small MOC effect, which means a correspondingly low SNR at 4 $\mathrm{kHz}$. It is presumed the SNR could be improved by longer averaging. However, in the present study the idea was to use the default protocol and measure how well it performed. The conclusion is that it is quite satisfactory for global values of the evoked signal. Nevertheless, because the effect is so small the most important thing is to get high quality recordings with appropriate SNRs.

The TEOAE response levels exhibited a frequency pattern in which the maximum occurred in the $1.4 \mathrm{kHz}$ half-octave frequency band, similar to other studies using the same equipment [24]. The reliability was around $0.3 \mathrm{~dB}$ for the broadband signal and reached $0.5 \mathrm{~dB}$ for some frequency bands. It was best at $2 \mathrm{kHz}$. This is generally consistent with previous studies, especially [25], where reliability was also best at $2 \mathrm{kHz}$. In [26], similar values of SEM were achieved (less than $1 \mathrm{~dB}$ ), but the highest SEM values were at $1 \mathrm{kHz}$, which was attributed to low-frequency noise. Here high frequencies also generated quite high variability as well. In [27], SEMs were much higher, reaching even $2 \mathrm{~dB}$, but in that study the consecutive measurements were made over a 1-year time-span.

Finally, the limitations of this preliminary study should be mentioned. The group studied was quite small; in addition, studies across longer time-spans are needed. There is also the possibility of a middle-ear muscle reflex confounding the results, as there is the possibility of activation in some subjects even with a $60 \mathrm{~dB}$ SPL stimulus [28]. Additionally, some studies have shown that the level of conscious attention may exert an MOC effect on OAEs [4]. This effect is very small and was not controlled here; it is unlikely that control of it would be required in clinical testing.

Nevertheless, this study has arrived at one important finding, that even during a single session the variability of the suppression effect is quite high. Moreover, the suppression effect is only slightly higher than the variability, or sometimes even less so (as for the $4 \mathrm{kHz}$ band).

In the present work the results are shown in decibels, rather than in percent as in some recent work [18]. This approach was in keeping with showing results for a particular system under its default settings, rather than investigating the MOC effect more generally, as has been done in other studies $[8,16-18]$.

\section{Conclusions}

The data analysis has revealed that, for the paradigm used, the reliability of suppression of TEOAEs is quite satisfactory for a broadband signal and for half-octave bands between 1 and $2 \mathrm{kHz}$. For higher frequencies, the variability is higher, and given that the suppression effect is then lower, the variability is of the same size as the suppression effect. In order to measure small suppression effects, measurements must be done carefully so as to minimize noise sources and very strict criteria for detection of OAEs are needed.

\section{Acknowledgment}

The study was partially supported by the grant OPUS 2014/15/B/NZ4/00700 financed by the Polish National Science Centre.

\section{References:}

1. Kemp DT. Stimulated acoustic emissions from within the human auditory system. J Acoust Soc Am, 1978; 64(5): 1386-91.

2. Taranda J, Maison SF, Ballestero JA, Katz E, Savino J, Vetter $\mathrm{DE}$ et al. A point mutation in the hair cell nicotinic cholinergic receptor prolongs cochlear inhibition and enhances noise protection. PLoS Biol, 2009; 7(1): e18.

3. Kawase T, Delgutte B, Liberman MC. Antimasking effects of the olivocochlear reflex. II. Enhancement of auditory-nerve response to masked tones. J Neurophysiol, 1993; 70(6): 2533-49.

4. de Boer J, Thornton AR. Effect of subject task on contralateral suppression of click evoked otoacoustic emissions. Hear Res, 2007; 233(1-2): 117-23.
5. Tavartkiladze GA, Frolenkov GI, Artamasov SV. Ipsilateral suppression of transient evoked otoacoustic emission: role of the medial olivocochlear system. Acta Otolaryngol, 1996; 116(2): 213-18.

6. Collet L, Kemp DT, Veuillet E, Duclaux R, Moulin A, Morgon A. Effect of contralateral auditory stimuli on active cochlear micro-mechanical properties in human subjects. Hear Res, 1990; 43(2-3): 251-61.

7. Stuart A, Preast JL. Contralateral suppression of transientevoked otoacoustic emissions in children with sickle cell disease. Ear Hear, 2012; 33(3): 421-29.

8. Mishra SK, Lutman ME. Repeatability of click-evoked otoacoustic emission-based medial olivocochlear efferent assay. Ear Hear, 2013; 34(6): 789-98. 
9. Namyslowski G, Morawski K, Kossowska I, Lisowska G, Koehler B, Jarosz-Chobot P. Contralateral suppression of TEOAE in diabetic children. Effects of $1.0 \mathrm{kHz}$ and $2.0 \mathrm{kHz}$ pure tone stimulation: preliminary study. Scand Audiol Suppl, 2001; (52): 126-29.

10. Ugur AK, Kemaloglu YK, Ugur MB, Gunduz B, Saridogan C, Yesilkaya E et al. Otoacoustic emissions and effects of contralateral white noise stimulation on transient evoked otoacoustic emissions in diabetic children. Int J Pediatr Otorhinolaryngol, 2009; 73(4): 555-49.

11. Kaf WA, Danesh AA. Distortion-product otoacoustic emissions and contralateral suppression findings in children with Asperger's Syndrome. Int J Pediatr Otorhinolaryngol, 2013; 77(6): 947-54.

12. Sliwinska-Kowalska M, Kotylo P. Occupational exposure to noise decreases otoacoustic emission efferent suppression. Int J Audiol, 2002; 41(2): 113-19.

13. Knudson IM, Shera CA, Melcher JR. Increased contralateral suppression of otoacoustic emissions indicates a hyperresponsive medial olivocochlear system in humans with tinnitus and hyperacusis. J Neurophysiol, 2014; 112(12): 3197-208.

14. Geven LI, Wit HP, de Kleine E, van Dijk P. Wavelet analysis demonstrates no abnormality in contralateral suppression of otoacoustic emissions in tinnitus patients. Hear Res, 2012; 286(1-2): 30-40.

15. de Boer J, Thornton AR. Neural correlates of perceptual learning in the auditory brainstem: efferent activity predicts and reflects improvement at a speech-in-noise discrimination task. J Neurosci, 2008 ; 28(19): 4929-37.

16. Stuart A, Cobb KM. Reliability of measures of transient evoked otoacoustic emissions with contralateral suppression. J Commun Disord, 2015; 58: 35-42.

17. Mertes IB, Goodman SS. Within- and across-subject variability of repeated measurements of medial olivocochlear-induced changes in transient-evoked otoacoustic emissions. Ear Hear, 2016; 37(2): e72-84.
18. Marshall L, Lapsley Miller JA, Guinan JJ, Shera CA, Reed CM et al. Otoacoustic-emission-based medial-olivocochlear reflex assays for humans. J Acoust Soc Am, 2014; 136(5): 2697-713.

19. Marshall L, Heller LM. Reliability of transient-evoked otoacoustic emissions. Ear Hear, 1996; 17(3): 237-54.

20. Jedrzejczak WW, Blinowska KJ, Konopka W. Resonant modes in transiently evoked otoacoustic emissions and asymmetries between left and right ear. J Acoust Soc Am, 2006; 119(4): 2226-31.

21. Beattie RC, Kenworthy OT, Luna CA. Immediate and shortterm reliability of distortion-product otoacoustic emissions. Int J Audiol, 2003; 42(6): 348-54.

22. Kemp DT, Ryan S, Bray P. A guide to the effective use of otoacoustic emissions. Ear Hear, 1990; 11(2): 93-105.

23. Lisowska G, Namyslowski G, Orecka B, Misiolek M. Influence of aging on medial olivocochlear system function. Clin Interv Aging, 2014; 9: 901-14.

24. Jedrzejczak WW, Koziel M, Kochanek K, Skarzynski H. Otoacoustic emissions in smoking and nonsmoking young adults. Clin Exp Otorhinolaryngol, 2015; 8(4): 303-11.

25. Harris FP, Probst R, Wenger R. Repeatability of transiently evoked otoacoustic emissions in normally hearing humans. Audiology, 1991; 30(3): 135-41.

26. Keppler H, Dhooge I, Maes L, D’haenens W, Bockstael A, Philips B et al: Transient-evoked and distortion product otoacoustic emissions: A short-term test-retest reliability study. Int J Audiol, 2010; 49(2): 99-109.

27. Lapsley Miller JA, Marshall L, Heller LM. A longitudinal study of changes in evoked otoacoustic emissions and pure-tone thresholds as measured in a hearing conservation program. Int J Audiol, 2004; 43(6): 307-22.

28. Guinan JJ Jr, Backus BC, Lilaonitkul W, Aharonson V. Medial olivocochlear efferent reflex in humans: otoacoustic emission (OAE) measurement issues and the advantages of stimulus frequency OAEs. J Assoc Res Otolaryngol, 2003; 4(4): 521-40. 